\title{
Empowerment and Enrichment Principles in the Philosophy of Pucuk Rebung Motives of Karawang Gayo
}

\author{
Abidah $^{1}$, Al Misry ${ }^{2}$, Luqmanulhaqim ${ }^{3}$, Susidamaiyanti $^{4}$, Isnawati $^{5}$ \\ 1,2,3,4,5 Institut Agama Islam Negeri Takengon, Indonesia \\ abidah_aceh@yahoo.co.id
}

\section{Abstract}

The aim of this paper is to discover the principles or patterns of empowerment and enrichment in the philosophy of Pucuk Rebung (bamboo shoots) in the motives of Kerawang Gayo. The method of this research is ethnographic method with interview data collection techniques, and study of the kerawang gayo text. Respondents of the research were the chairman of the Gayo customary assembly, traditional leaders, and community leaders. The method used is an ethnographic domain analysis. The research results shows that there are 7 principles of empowerment and enrichment based on local wisdom of openwork gayo motives, namely enlargment and betterment, sustainable leading, professional assistance, competency rechargement, professional employee strategic placement, consistency strengthening and improvement maintenance. The research results shows that there are 7 principles of empowerment and enrichment based on local wisdom of openwork gayo motives, namely enlargment and betterment, sustainable leading, professional assistance, competency rechargement, professional employee strategic placement, consistency strengthening and improvement maintenance. The method used is an ethnographic domain analysis. The research results shows that there are 7 principles of empowerment and enrichment based on local wisdom of openwork gayo motives, namely enlargment and betterment, sustainable leading, professional assistance, competency rechargement, professional employee strategic placement, consistency strengthening and improvement maintenance. The method used is an ethnographic domain analysis. The research results shows that there are 7 principles of empowerment and enrichment based on local wisdom of openwork gayo motives, namely enlargment and betterment, sustainable leading, professional assistance, competency rechargement, professional employee strategic placement, consistency strengthening and improvement maintenance.
Keywords

empowerment; enrichment; shoots shoots

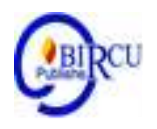

\section{Introduction}

This paper discusses the model empowerment and enrichtmentin the philosophy of shoots of bamboo shoots on the Kerawang Gayo fabric motif, Aceh, Indonesia. Gayo filigree is a characteristic of the carving motifs found in the indigenous Gayo tribe located in the highlands of Aceh, Indonesia. This Gayo Kerawang motif can be found on the traditional cloth of the Gayo community, on wood carvings, on the walls of houses / buildings or even in other crafts in the form of pottery or jugs. Overall, each region has a typical cloth of a region, for example the Javanese are known for their batik, North Sumatra for their ulos cloth, even in North America the Indians have a typical Pueblo cloth, namely Navajo motif cloth (Tiffany S. Lee, 2009 ), the traditional cloth of Timor Leste is the Tais cloth (Barbara 
Jeronimo Doutel Sarmento (2016). In this article, we want to explore the values of the motifs contained in the Gayo Kerawang cloth, namely the traditional cloth of the Gayo tribe of Aceh, Indonesia.

The study of traditional cloth motifs is important because the motifs in the form of carvings or weaving have meaning, are spiritual and each design flows in the mind of the maker. There is a separate form of communication such as communicating about history, culture, and family, especially those contained in each design (Tesa Afriliani: 2015). Likewise with the Gayo Kerawang cloth, whose motifs are inspired from plants and interpretations of nature, so that they have very strong philosophical values.

There are seven forms of carving on the Gayo openwork motif, namely matanilo, tapak sleman, emun depart, puter Tali, shoots of bamboo shoots / tuis, tini kukur, peger / jang (Ibrahim: 2007). Of the seven Gayo openwork motifs above, one motif that has caught the attention of the author is shoots of bamboo shoots / tuis. This bamboo shoot motif has a high philosophy, related to the empowerment of a person. Therefore, exploration of the philosophical values of bamboo shoots and their relation to organizational behavior, especially those related to enrichment and empowerment, is important.

The concept of Empowerment and enrichment in the world of work is very much needed, because employees who work are human beings who have a sense, creativity and initiative as a manifestation of their human elements, so that there are employees who are very ambitious, totality, visoiner, need for achievement. Conversely, there are employees who are not ambitious, have no initiative, low work ethic, low work skills, or who have been in a certain position for too long, so that the employee becomes unproductive or novice employees who do not have enough experience. For such employees, empowerment and enrichment efforts are needed so that the world of work or the organization runs according to the vision and mission of the institution. Community empowerment as an application of government programs requires full enthusiasm from the community itself so that they will make every effort to improve the quality of their human resources in a total and continuous manner. Many efforts have indeed been carried out by the government, one of which is by providing assistance which is directly channeled to remote villages to support village development and the development of local potentials that are undoubtedly empowered. (Mawardi et al, 2019).

By increasing job enrichment, it will also increase employee motivation. Raza, MA \& Nawaz, MM (2011: 221) explained that motivation can be increased in various ways, including by providing job enrichment for employees. The same thing as explained by Batram and Casimir (2007: 4-19) in their research that empowerment has a significant positive correlation both with performance and job satisfaction, meaning that empowerment is an important factor in determining employee performance and job satisfaction. The importance of empowerment is explained in other studies such as that conducted by Tjiptono Fandy (2000), which states that empowerment can be interpreted as involvement of employees who are truly meaningful or significant. In order to continue to grow, employees need space to actualize themselves both mentally and abilities. Employees who are given empowerment will show a more flexible attitude in dealing with existing changes.

Some of the quotes above show the importance of empowerment and enrichment, therefore in empowerment and enrichment efforts, certain principles are required in their actions, so that these efforts are successful in accordance with these empowerment and development goals. Lots of empowerment and enrichment principles as mentioned by Andre (2008) Wexley and Yukl (1977) Greenberg and Baron explain the importance of employee development by paying attention to dimensions that can affect job enrichment. Of the three 
authors above, none of them studied the principles of empowerment and enrichment based on a cultural approach. Therefore, it is important to conduct empowerment and enrichment studies based on local culture, in this case the local wisdom of the Gayo Kerawang Gayo tribe, Aceh, Indonesia.

\section{Review of Literature}

Enrichment is employee development, while empowerment means employee empowerment. Enrichmentnamely: development and enhancement through specific assignments or assignments, this is a common form of career development. (Moeheriono: 2014) One form of enrihcment is a succession plan, which is a program designed to examine and prepare employee candidates to fill positions or positions in certain companies or institutions.

Richard Carver, Managing Director of the Coverdale Organization, According to him, the meaning of empowerment is an effort made to encourage and allow someone to take personal responsibility for improving or improving ways of completing work so that it can increase contributions in achieving organizational goals. Empowerment in this sense requires creation culture_which encourages employees at all levels to do something different and helps employees to have confidence and the ability to change.

Priyono and Pranarka, the meaning of empowerment actually has two meanings, the first is empowerment has the role of giving power or being able to transfer it to other parties. While the second can be understood if the meaning of empowerment is an effort to provide empowerment and abilities to other parties (Priyono and Pranarka, AMW: 1996). The purpose of empowerment or empowerment is to form individuals and communities to become independent. This independence includes the independence of thinking, acting and controlling what they do. Community independence is an ability consisting of cognitive, conative, psychomotor, affective abilities, by mobilizing resources owned by the community's internal environment.

Employee empowerment is a philosophy and strategy that a company uses to provide space for its employees to make decisions and behave according to company goals. This strategy gives employees a greater sense of pride and ownership in their work. Having room to make their own decisions also encourages them to think creatively and innovate.

Employee empowerment can be a gentle yet effective motivational tactic. In addition to increasing company productivity, employees will also feel more satisfied. This in turn can have a positive impact on the company's culture, both internally and in external relations. studyindicates that employees who are empowered by the company will have a fifty percent higher satisfaction rate. Unfortunately, many companies focus too much on empowering consumers, and instead ignore their own employees. In supervision, there is the meaning of helping (asisting), giving support (supporting), inviting to participate (sharing).

Syardiansyah et al, (2020) the following: a). Career planning and development, the results of performance appraisal are used to determine one's career path opportunities. This means that for those who experience performance improvements, promotions will be made. b). Training and development needs, performance objectives for training and development needs are intended for employees who lack capability or expertise. The aim of the training is to boost employee performance in order to become better. c). Compensation adjustments, employees who perform well of course compensation will increase the amount in accordance with company regulations.

Moeheriono (2014) Development of employees in human resource management aims to maintain (maintenance) employees by developing them, according to their competencies, 
talents and abilities, so that they can function properly and optimally for the company. Finally, the researcher concluded that a successful leader can succeed in his subordinates.

Heathfield (2012) explains that Empowerment plays an important role in employee satisfaction thereby increasing their performance in the organization. Empowerment is also defined as a process that allows and gives authority to individuals to think, behave, take action and make decisions and control work independently. It is the feeling of self control of one's own destiny.

Then empowerment can also be interpreted as one of the solutions for those who experience powerlessness so that they participate in feeling the results of development that they have not fully felt, this is because development is actually considered as something that weakens the position of vulnerable communities. (Adiwijaya et al, 2018)

Wexley and Yukl suggest that training and development are terms related to conscious and planned efforts, which are organized to achieve mastery of skills, knowledge, and attitudes of employees or organizational members. The organization implements training and development in the form of planned programs. By choosing the right type of training as well as development, the organization can ensure that employees have the right skills. This will be the need for organizations to be continuously updated in the follow-up of HR practices (Wexley, KN \& Yukl, GA 1977: 282).

Lots of research has been conducted regarding how effective employee development is like that of Irene fergusonlaing in her research entitled The Impact Of Training And Development On Worker Performance and Productivity in Public Sector Organizations: A Case Study Of Ghana Ports and Harbors Authority. In this study, it was stated that through training and development, employees are an effective tool to achieve success, both personal and organizational (Irene Ferguson Laing: 2009).

\section{Research Methods}

This study uses a cultural approach, therefore mEthnographic ethod is the appropriate method in this research. The data collection technique used ethnographic interviews with a special speech. The data sources are the Gayo Traditional Council, traditional leaders, community leaders, elders in the community. The analysis used is domain analysis by means of rechecking field notes to look for cultural symbols and looking for relationships between these symbols.

\section{Discussion}

Traditional cloth or regional clothing or traditional cloth is a costume that shows identity which is usually associated with the territorial or geographic area of an area, or is also associated with the historical area of a particular social or religious area. or traditional cloth is also interpreted as a costume that represents the culture of a certain ethnic group. The traditional fabric of the Gayo community which is the identity of the Gayo tribe is the Gayo openwork cloth. Joni (2017: 25) Kerawang consists of the words "Ker" and "Rawang" Ker = power of thought, abstract design occurs spontaneously, rawang = predictions or imagery from the natural phenomenon of the openwork universe, which is a form of spontaneous imagination. Kerawang Gayo is the embodiment of imagination created spontaneously and a combination of the phenomenon of natural beauty and its contents with the character and social status of humans according to the philosophy and meaning implied by the wider world. 
Kerawang Gayo is a variety or motif in decorating cloth (Ummi Sakinah: 2016, 74-82). The process of making Gayo openwork is done by damping on the cloth which is free to move back and forth (Leigh, Barbara, 1989: 132). Upuh ulen-ulen is a long garment or cloth which is a symbol of greatness and respect for the customs of the Gayo people, which is the philosophy of life of the Gayo people which is referenced to the Gayo Kerawang embroidery carving (Herawati and Tjut Zahara, 2011).

One of the motives that is the focus of writing this article is motive Bamboo shoots often referred to as tuis, namely bamboo shoots (bamboo shoots) this is a symbol of the younger generation who are born / successors. M. Jusin Shaleh, 2019 explained that in the Gayo rimbun language, there are different meanings of bamboo shoots in what is meant by tuis. or as stated by H. Abd Kadir Wahid, as explained by Joni who lives in Boom village, he explained that the shoots of bamboo shoots were not bamboo shoots or tuis, but the tops of the trees were cut slanted by Joni. In this case the writer agrees on shoots of bamboo shoots in the meaning of the tuis, this is based on the philosophical expressions that follow. Following are the shoots of bamboo shoots

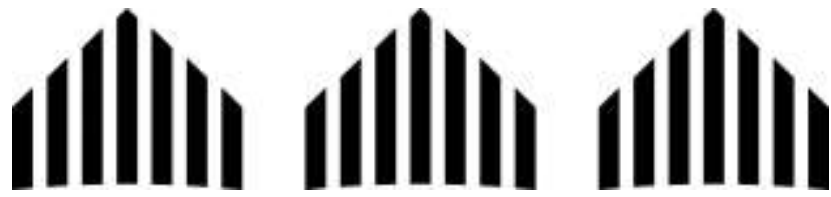 \\ Figure 1. Bamboo Shoot Shoots Pictures}

The base of the lower part of the bamboo shoot / tuwis body is large and rather wide, while the top or shoot is pointed. In this paper, shoot shoots are often referred to as tuis, namely bamboo shoots (bamboo shoots), this is a symbol of the younger generation who are born / successors. This symbol is then packaged in a traditional expression of the Gayo community's wisdom as:

\begin{tabular}{|l|l|}
\hline $\begin{array}{l}\text { Kucak ber kul, } \\
\text { Konot ber naru } \\
\text { Tuah berpapah }\end{array}$ & $\begin{array}{l}\text { Translate: } \\
\text { Small was raised } \\
\text { Short in length } \\
\text { To get luck / luck must be carried }\end{array}$ \\
$\begin{array}{l}\text { Bahgie bertona } \\
\text { Ogoh igurunen } \\
\text { Pane i pergunen }\end{array}$ & $\begin{array}{l}\text { To get happiness must be guided / guided } \\
\text { stupid to entrust a teacher (taught) } \\
\text { good at being used }\end{array}$ \\
\hline
\end{tabular}

Ibrahim Kadir explained that small bamboo shoots must be maintained to become adults, knowledge that is still a little must be expanded by submitting it to education (knowledgeable teachers), luck is always pursued, guided, to achieve something, good existence is always grateful, the stupid must be educated, illiteracy cannot be justified, after having smart knowledge (intelligence) it must be used for the benefit of the wider community.

The organization is analogous to family life, then dIn the realm of life in the family, parents are obliged to care for the benefit of the child from childhood to adulthood, surrender the child to the world of education in order to become a useful person in the afterlife, if you have knowledge, you must use it for the sake of society (Ibrahim Kadir). Jusin Saleh explained that Tuis is a symbol of a generation where a mother protects her child very 
strongly and firmly, as evidenced by the existence of tuis in the middle of other mature bamboo. In addition, the tuis has turned into an adult, the mother's care cannot be separated, as evidenced by the presence of neniyun (bamboo stalks) in the middle of the bamboo, therefore the mother's love takes care of her children all the time until the child even grows up. The care of this child is often followed by the traditional Gayo expression that the bujang. Jusin Saleh further explained that this educational model was carried out directly, for example when the season should be sowing rice, then the bebujang game (teenagers are tops, this means parents want to teach their children to sharpen wood for their paddy nursery fences which ends with making a top. During the harvest season, the game that appears is the kite because the father teaches his son to split bamboo to make a cage, a type of sawung, which stores the harvest of rice.

Ar Hakim Aman Pinan (133) explained that bamboo shoots, the taller the man is, he feels himself smaller (not arrogant, greedy, arrogant and joyful. After transforming into bamboo stalks, this plant has very strong roots, this means that the stance is firm, and bamboo this is very useful for human needs.

Departing from the above philosophy, one should have the philosophical behavior of shoots as mentioned above. namely being nurtured, guided education is carried out, someone who does not yet have skills must be in the midst of an adept individual, always in an effort of maintenance and cannot be released but needs assistance and assistance from the care of his mother. Even after adulthood, it still needs education and maintenance throughout the ages, especially guidance in policies is needed because the more senior and in an already high position, the wave of problems becomes large and is sent to educational and training institutions, is hired according to their expertise, the personnel are not arrogant, cheerful, the higher the higher the stance, the smaller the inferiority.

In the theory of organizational preemptive in human resource management practice, this philosophy of shoots can be interpreted as enrichment \& empowerment. In Arabic it is

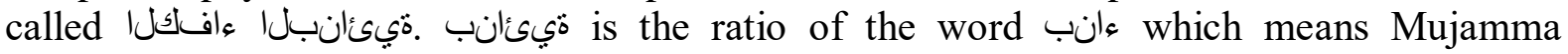
'allughah al arabiyah, $(1994,64)$

fo esu eht sa hcus stxetnoc lareves ni desu netfo osla si drow siht dna أق ام جداره وذ حوه fi'il انالف عنبت in the following sentence انبا مذختا which means (build). Alqur'an Surah As-Shams explains about Binaiyah, which is meant by its regular guidance.

و السما \& وما بنـها

Meaning: "And the heavens and their formation".

There are five core dimensions of a job that affect job enrichment typically contributing to people who enjoy work according to Greenberg and Baron:

a) Skill Variety, Increase the number of skills individuals use when doing work.

b) Task Identity, Enabling people to do work from start to finish.

c) Task Significance, Providing jobs that have a direct impact on the organization or stakeholders.

d) Autonomy, Increases the level of decision making, and the freedom to choose how and when work is done.

e) Feedback, Increase the amount of recognition for doing a good job, and communicate people's work.

Job Enrichtmen give workers more autonomy, responsibility and feedback. According to Andre (2008: 134) the indicators used are as follows:

a. Giving two or more tasks simultaneously (put two or more taska together) makes the work bigger, more meaningful and more challenging 
b. Create natural work units, build work based on important tasks

c. Build relationships with consumers (Establish client relationships), build direct relationships between workers and customers.

d. Expand jobs vertically, taking over some of the jobs previously assigned to management.

e. Opening feedback channels (open feedback channels), feedback can come from the job itself, customers or managers.

The two quotes above are principles or patterns that serve as roles in the enrichment effort. The results of this study provide a new concept which is explored from local wisdom which is poured on the gayo openwork motif, namely the symbol of shoots shoots. The symbol of the Gayo openwork shoots means regeneration or the next generation in terms of enrichment and empowerment human resource management (MSDM). Therefore there are several principles in the Gayo openwork-based enrichment and empowerment, namely

1. Enlargement and betterment, that there is a gradual career development where the employee's career is developed gradually in stages due to time and work ability. Employee development and empowerment requires tiered career certainty, so that employees have readiness to work.

One form of enrihcment is the succession plan, which is a program designed to examine and prepare employee candidates to fill positions or positions in the company. The suitability of the qualifications required in a certain position or position. The suitability check will show Moeheriono (2014: 324) explaining that, "Which individual or employee is most suitable to be nominated for a position or position, and what abilities or qualifications the candidate needs to add to suit the requirements of the position or position. He continued, he explained that the process of designing a career path and a regeneration program for an organization was carried out according to stages which included two main types of formulation,

In order for an institution or company to survive and survive for a long time, workers who work for that company need to be given a job redesign program such as job enrichment. With job enrichment, worker productivity can be increased so that workers do not feel monotonous with their work. Power holders need to be careful in seeing who the potential workers need to receive a job enrichment program.

2. Sustainable leading, ongoing mentoring. Continuous guidance and coaching in carrying out tasks by senior employees or superiors who are incidental or unplanned based on needs when carrying out tasks is needed as a form of continuous guidance. This mentoring effort can take the form of direct mentoring. mentoring is a strategic effort that has an impact on developing, engaging or retaining employees. Effective mentoring will have an impact on the existence of the institution.

3. Professional assistance, In the enrichment and empowerment efforts of workers / employees, assistance efforts are needed from professional workers, workers who are not yet proficient or beginners must be in the midst of employees who are already proficient, so that assistance efforts occur, in turn, in a short time the workers or employees have adapted and adept at the task assigned to him. Hoii Lai Wan, quoted from Employee Loyalty at the Workplace, argued that the more satisfied an employee is in knowing his work environment, the more likely it is that the employee will develop a sense of commitment to the organization in general.

4. Competency recharging, seminars, training, internships to other places, further studies are forms of formal and planned coaching, this recharging effort should be a strategic plan and a planned and operational program of an institution or company. Both employees who do not have sufficient knowledge and skills as well as employees who have long needed this recharging effort in order to keep up with the global dynamics and demands of the world 
of work with changes and accelerations that are so fast due to rapid global change, for that training, internships, further studies must be done.

5. Professional Employee Strategic Placement, learn from the philosophy of shoot shoots in gayo filigree, that workers who are skilled and have skills with competent competencies need to be given a strategic space or position because handing over an affair to an expert is an appropriate law / demand and on the contrary handing over an affair to a non-expert will happen destruction. Moeheriono (2014: 322) explains that enrichment is an effort to develop and improve through giving specific assignments or assignments, this is a common form of career development. This means that the development and empowerment of workers by providing trust with the right positions and tasks and giving broad authority to actualize themselves in carrying out the challenges of the world of work. Herxberg, an American psychologist, developed the enrichment idea by providing the opportunity to use the various abilities of workers by assigning greater tasks and responsibilities to employees and adding to the job in terms of quality, or complexity. For example, a technician who usually handles machines is then assigned to handle a new, more complex machine. Straub defines empowerment as granting autonomy, authority, trust, and encouraging individuals in an organization to develop regulations in order to complete work then tasked with handling the new, more complex machine. Straub defines empowerment as granting autonomy, authority, trust, and encouraging individuals in an organization to develop regulations in order to complete work then tasked with handling the new, more complex machine. Straub defines empowerment as granting autonomy, authority, trust, and encouraging individuals in an organization to develop regulations in order to complete work ${ }^{1}$ (Sadarusman, Eka. 2004.

6. Consistency Strenghtening strengthens employee consistensy,

The attitude of consistency that is explored from the Gayo openwork motive is the wisdom of the Gayo tribe community. Consistency is one of the soft skills a person must have in the world of work, social interaction in society. A person who is inconsistent is considered unsubstantiated and untrustworthy in the world of work and may be excluded from the midst of society.

A consistent attitude in ethics and organizational behavior is an important part that cannot be separated in management practice. There are many concepts that discuss the importance of being consistent. A person's attitude of consistency affects the behavior he does. This is as stated by Gea, that consistency can be understood as the suitability of words and actions (Gea, AA 2006: 16-26). Robbins explained that consistent means that each individual tries to align attitudes and behaviors to make it look rational and consistent. Robbins, SP, (2010: 41). This means that someone who is consistent means having a fixed attitude, always trying to harmonize his speech and behavior. Having a consistent attitude in an organization and in the world of work is a must, especially a leader in a work unit, without being ordered to be imitated and followed by subordinates or employees. Employees will be conditioned to appreciate a job even though the scope and weight of the work is relatively small. People who have a consistent attitude in carrying out a job are characterized by always being obedient and persistent in accordance with the intentions of the person concerned and the goals of the job. workers who are smart but inconsistent, do not have a significant influence on the development of the company or institution.

7. Improvement Maintenance, the maintenance of workers in the sense of maintenance and improvement, continuous guidance needs to be done even though the worker is at the top position, this is intended to ensure that workers are always in a controlled, controlled condition. Efforts to care for workers are not only for novice workers, even senior workers require worker care that is adapted to their conditions and needs, the more they are in the 
top position, the wave of problems and their complexity are also increasingly complex and large, therefore efforts to preserve or the concept of a continuous learning process (Continuous learning) is an offer in enrichment and empowerment.

Thus the 7 descriptions of the patterns or principles of empowerment and development of employees / workers above, these seven patterns are believed to be capable empowerment and enrichment concepts because this concept uses a traditional approach that has been used and has been a tradition for a very long time as old as the tribal civilization.

\section{Conclusion}

Based on the results of research on the symbols of the Gayo openwork motif, there are 7 (seven) principles of empowerment and enrichment, namely: First, Enlargement and betterment, is the principle of raising someone or making them better and more efficient by means of gradual career development efforts for employees, whether due to time or the condition of a person's work ability. Second, Sustainable leading, namely coaching or coaching with sustainable guidance. Third, professional assistants, workers who are not yet proficient or beginners must be in the midst of employees who are already proficient, resulting in mentoring and habituation efforts. Fourth, Competency recharging, employees who do not have sufficient knowledge and skills need training, internships to other places, further studies as an effort to develop their capacity. Fifth, Professional Employee Strategic Positioning, namely employees who have skills and expertise must function in certain fields who are competent with their expertise by placing employees strategically. Sixth, Consistency Strenghtening, namely the act of strengthening the consistency of employees, through efforts to provide guidance or motivation to the importance of a firm principle and a consistent attitude. Seventh, improvement maintenance, namely continuous maintenance of employees even though they are already in the top position even though they must always be in controlled maintenance efforts. These seven principles are believed to be effective in empowerment and enrichment efforts. through guidance or motivation, the importance of a firm principle and a consistent attitude. Seventh, improvement maintenance, namely continuous maintenance of employees even though they are already in the top position even though they must always be in controlled maintenance efforts. These seven principles are believed to be effective in empowerment and enrichment efforts. through guidance or motivation, the importance of a firm principle and a consistent attitude. Seventh, improvement maintenance, namely continuous maintenance of employees even though they are already in the top position even though they must always be in controlled maintenance efforts. These seven principles are believed to be effective in empowerment and enrichment efforts. 


\section{References}

Adiwijaya, S. et al. (2018). Empowerment Pattern for Thalasemi Patients in Dr. Soetomo Hospital Surabaya (Study of the Association of Parents with Thalassemia Indonesia, Surabaya). Budapest International Research and Critics Institute-Journal (BIRCIJournal). P. 289-298.

AR. Hakim Aman Pinan. (2003). Pesona Tanoh Gayo, Takengon: Pemerintah Kabupaten Aceh Tengah,

Andre, R (2008) organizational Behaviour-An Introduction to your life in organization. New Jersey: Pearson Education. P. 134

Bartram, T. and G. Casimir., (2007). The relationship between leadership and follower inroleperformance and satisfaction with the leader: The mediating effects of empowerment andtrust in the leader. Leadership and Organization Development Journal, Volume 28, No. 1,pp. 4-19

Barbara Jeronimo Doutel Sarmento, (2016), Strategi Pengembangan Kain Tenun Tradisional Tais Hasil Modifikasi Sebagai Daya Tarik Wisata Dili Di Timor Leste, Tesis, Program Pascasarjana Universitas Udayana Denpasar 2016, https://sinta.unud.ac.id.

Gea, A.A.( 2006). Integritas diri: keunggulan pribadi tangguh. Character Building Journal, 3 (1): 16-26. Diunduh Agustus. 2020 dari http://eprints.binus.ac.id/

Heathfield, S. M. (2012). Training: Your investment on people development and retention. About.com Guide. Human Resource [on-line]: http://humanresources.about.com/od/educationgeneral/a/training_invest.htm.

Herawati dan Tjut Zahara, (2011), Buku Ajar Tradisional Aceh. Banda Aceh: Fkip Pkk Unsyiah

Irene Ferguson Laing, (2009), "The Impact of Training and Development on Worker Performance and Productivity in Public Sector Organizations: A Case Study OfGhana Ports and Harbours Authority".Institute of Distance Learning-KNUST.

Ibrahim Kadir, (2007), Makna, Pengertian, Filsafat, yang terkandung dalam Ukiran Motif Gayo, Kabuaten Aceh Tengah, (Kabupaten Aceh Tengah), Catatan tidak diterbitkan

Jamiul Huquq Mahfudzah, (2017), Munjid, (Lebanon: Darul Masyriq)

Joni dkk, Kerawang Gayo, (2007), Tingkis ulak ku bide, Sesat ulak ku dene, (Tangerang: Mahara Publishing)

Ummi Sakinah dll, (2016) Jurnal Ilmiah Mahasiswa Pendidikan Kesejahteraan Keluarga Vol: 1 No: 1.

Leigh, Barbara. (1989), Tangan-Tangan Terampil: Seni Kerajinan Aceh, (Jakarta: Jambatan)

Mawardi et al, (2019). Agenda Empowerment of People in Tarmizi Taher Point of View. Budapest International Research and Critics Institute-Journal (BIRCI-Journal). P. 443450.

M. Jusin Shaleh, (2019), Ketua Majelis Adat Gayo Kabupaten Aceh Tengah, wawancara di Takengon, 2 Agustus 2019

Moeheriono, (2014), Pengukuran Kinerja: Berbasis Kometensi, Jakarta: PT. Raja Grafindo Persada

Mujamma' allughah al arabiyah, Mu'jam al-Wajiiz, (Mesir: Wizarah at-Tarbiyah wa Ta'liim, 1994), h.64.

Priyono dan Pranarka, A.M.W. (1996) Pemberdayaan Konsep, Kebijakan dan Implementasi dalam Panarka dan Vidyandika Moeljarto, Pemberdayaan (Empowerment) (Jakarta: CSIS)

Raza, MA \&Nawaz, MM (2011) october. impact of Job Enrichtment: Evidence from public sector of pakistan. European journal of social sciences 
Robbins, SP, (2010), Manajemen, (Jakarta: Erlangga)

Tesa Apriliani, (2015), Aplikasi Teknik Sablon Dengan Objek Simbol Navajosebagai Element estetik ruangan, Universitas Pendidikan Indonesia |repository.upi.edu|perpustakaan.upi.edu.

Tjiptono, Fandy. 2000. Manajemen jasa, Edisi Kedua. Yogyakarta: Penerbit Andi.

Tiffany S.Lee, (2009), Language, Identity, and power: Navajo and Pueblo young adults'perspectives and Experiences with competing language ideologies, Journal of language identity\&education November 2009, DOI: 10.1080/15348450903305106 http://www.researchgate.net/publication/233040680

Sadarusman, Eka. (2004), Pemberdayaan: Sebuah Usaha Memotivasi Karyawan, Fokus Ekonomi, Vol.3, No 2

Syardiansyah et al, (2020). The Effect of Job Satisfaction and Organizational Culture on Employee Performance of the Royal Hotel in East Aceh Distric. Budapest International Research and Critics Institute-Journal (BIRCI-Journal). P. 849-857.

Wexley dan Yukl (1977), Organizational behavior and personnel psychology.Homewood, IL: Irwin. 